\title{
Does Profitability, Firm Size, and Investment Opportunity Set Affect Earnings Quality?
}

\author{
Budi Andriani, ${ }^{1 *}$ Mahfud Nurnajamuddin, ${ }^{2}$ and Khairina Rosyadah ${ }^{\mathbf{3}}$ \\ ${ }^{1,2}$ Department of Management, Faculty of Economic and Business, Universitas Muslim Indonesia, \\ Makassar City, Indonesia \\ ${ }^{3,}$ Department of Management, STIM LPI, Makassar City, Indonesia \\ Email Address: \\ budiandrianimt@umi.ac.id, mahfud.nurnajamuddin@umi.ac.id
}

\begin{abstract}
This paper examines the relative importance of firm size, investment opportunity set, and probability in predicting earnings quality. This study's research method involves using quantitative data. The purpose of this study is to analyze companies in Indonesia that publish financial reports and disseminate them on the Indonesia Stock Exchange. The study population is the financial statements of manufacturing companies in the consumer goods industry sector that are listed on the IDX as many as 50 companies with purposive sampling technique so that it becomes 38 company financial reports with two years of data so that the total sample to 76 financial statement data. The data collected from the Indonesian stock exchange were analyzed by multiple regression using ordinary least squares with the Eviews software (V.11). The results of the study show that profitability, size, and investment opportunity are positively correlated with higher-quality earnings. Consequently, the company's profitability has a positive and significant effect on its financial performance, meaning that the more profitable a company, the stronger its earnings. Company size is positively affected by the earnings quality of a company, meaning that larger companies reward higher quality earnings. The investment opportunity set has a positive and significant effect on earnings quality, which means that earnings quality increases because more investors are interested in investing.
\end{abstract}

Keywords: Probability, Size Firm, Investment Oppurtunity Set, Earnings Quality.

Abstrak: Makalah ini membahas kepentingan relatif dari ukuran perusahaan, set kesempatan investasi, dan probabilitas dalam memprediksi kualitas laba. Metode penelitian penelitian ini melibatkan penggunaan data kuantitatif. Penelitian ini bertujuan untuk menganalisis perusahaan di Indonesia yang mempublikasikan laporan keuangan dan menyebarluaskannya di Bursa Efek Indonesia. Populasi penelitian adalah laporan keuangan perusahaan manufaktur sektor industri barang konsumsi yang terdaftar di BEI sebanyak 50 perusahaan dengan teknik purposive sampling. Menjadi 38 laporan keuangan perusahaan dengan data dua tahun sehingga jumlah sampel menjadi 76 data laporan keuangan. Data yang terkumpul dari Bursa Efek Indonesia dianalisis dengan regresi berganda menggunakan ordinary least squares dengan software Eviews (V.11). Hasil studi menunjukkan bahwa profitabilitas, ukuran, dan peluang investasi berkorelasi positif dengan laba berkualitas lebih tinggi. Dengan demikian, profitabilitas perusahaan berpengaruh positif dan signifikan terhadap kinerja keuangannya, artinya semakin menguntungkan suatu perusahaan maka semakin tinggi pula labanya. Ukuran perusahaan dipengaruhi secara positif oleh kualitas 
laba perusahaan, yang berarti bahwa perusahaan yang lebih besar menghargai laba dengan kualitas yang lebih tinggi. Set kesempatan investasi berpengaruh positif dan signifikan terhadap kualitas laba, artinya kualitas laba meningkat karena semakin banyak investor yang tertarik untuk berinvestasi.

Kata Kunci: Probabilitas, Ukuran Perusahaan, Set Peluang Investasi, Kualitas Laba.

\section{INTRODUCTION}

To increase competitiveness, a company must have an advantage in competing with other companies. Companies not only create satisfying products for consumers but also must be able to manage finances well. Every company strives to display earnings information that is always a concern of financial statement users and investors alike to show good performance. Financial performance can be seen from the company's financial statements by analyzing its financial statements, namely the statement of financial position and income statement (Asniwati, 2020).

Financial statement analysis is basically used to view a company's viability and the stability of a business, sub-business, or project. These reports are usually submitted to the company's top management to determine the level of management achievement, find out about the company's development from one period to the next, and as a reference or attitude to adopt company policies (Sanjaya and Rizky, 2018). Companies have many types of financial reports, depending on the purpose and purpose of making these financial reports. Each financial report has its meaning about the company's financial status. However, companies need to prepare several financial reports according to predetermined standards, especially for their interests and other interests (Maulidasari, 2020)

Profit gives essential meaning to the company. Companies must provide financial reports to various stakeholders. The aim is to provide relevant and timely information to help make investment decisions, monitor, reward performance, and make contracts (Mahkamah et al., 2020). Profit gives an essential meaning to the company. Companies must provide financial reports to various stakeholders (Polii et al., 2019). The aim is to provide relevant and timely information to help make investment decisions, monitor, reward performance, and make contracts. (Agustin and Hermanto, 2015).

The quality of earnings data is important because it is a tangible manifestation of a company's financial performance, as reflected in the income statement. It is critical information for investors to make investment decisions or forecast future profits (Zatira et al., 2020). High-quality earnings information will be a good signal for investors to invest; on the other hand, low-quality earnings information will signal poor resource allocation, resulting in errors in decision-making by information users such as investors and creditors (Kurniawan and Aisyah, 2020). Earnings quality can also be defined as the ability of earnings data to respond to market conditions, whereas earnings reporting can respond to market conditions. A different statement by (Marsela and Maryono, 2017) states that poor earnings quality is caused by managers' use of earnings management practices; this is due to management's ineffectiveness in preparing financial reports for internal and external parties. 
Earnings quality is an essential aspect in assessing an entity's financial health, but investors, creditors, and other users of financial statements often ignore it (Marpaung, 2019). (Dewi and Yadnyana, 2019) state that earnings information plays an essential role in measuring the change in net shareholder wealth and indicates a company's ability to generate profits. Through profit, investors and creditors can evaluate management performance, predict investment risks, and can predict future earnings (Kurniawati, 2016).

The financial statement manipulation scandal has raised questions over the reliability of financial statements. The manipulation scandal was carried out by Toshiba, which shocked the whole world in May 2015. Toshiba stated that its company was investigating an internal accounting scandal and had to revise its profit calculations in the last three years. The announcement was very unexpected because Toshiba has become the emblem of a powerful Japanese company. After thorough investigation, it was discovered that Toshiba had been struggling to achieve its business profit target since 2008, at a time when there was a global crisis. The crisis also hit Toshiba's business until finally, Toshiba committed a lie through accounting fraud valued at US \$ 1.22 billion. This action was carried out with various efforts to generate profits that did not match reality.

A scandal also occurred at PT Hanson International, which the Financial Services Authority (OJK) found to manipulate the 2016 Annual Financial Report (LKT) presentation. It is known that the statement in the accounting report relates to the sale of ready-to-build lots (Kasiba) with a total value of Rp. 732 billion. OJK questioned the full accrual of accounts receivable; the transaction was not disclosed in the 2016 LKT. Another scandal carried out by Garuda Indonesia recorded in the 2018 financial statements of a collaboration transaction receivable with PT Mahata Aero Teknologi (Mahata) in connection with providing an in-flight WiFi connection, with total revenue of US \$232.94 million, this value is shown in the published annual financial statements for the 2018 period (www.cnnindonesia.com, 2019).

The use of an accrual basis in financial statement preparation causes this financial statement manipulation. Accrual-based measurement allows company management to make financial statement changes to achieve the desired profit value, attract investors, and increase the stock price (Sari, 2020). Users of financial reports, such as investors and creditors, will make mistakes in their decision-making due to poor earnings quality. If the data does not reflect actual performance, management may mislead report users. On the other hand, high-quality earnings are the best decisions because they meet the qualitative characteristics of financial statements, such as relevance and reliability (Warianto \& Rusiti, 2014).

Earnings quality is a profit indicator that accurately reflects the profitability of a business' operations. The ability of a company to generate operating profit is referred to as profitability (Amin, 2015). Profit is required for a business to continue operating; it must be in good shape. It will be difficult for the company to attract outside capital if there is no profit (Muhammad and Rahim, 2015). The main focus in evaluating company performance is the company's ability to generate profits in business activities, because profits are not only an indicator of the company's ability to meet its investors' obligations, but they also become a factor in creating company value, which shows the company's prospects (Sanjaya and Rizky, 2018).

Profitability (ROA) is a metric used by (Ginting, 2017) to assess a company's efficiency in generating profits and utilizing its assets. The higher the profit level of a 
company, the higher the ROA, the higher the quality of the company. Profit is calculated using the profitability ratio that the majority prefers. Comparisons between the various components of the financial statements, particularly the financial position statement and the income statement, can be used to calculate profitability ratios. Investors prefer to invest in companies that have a high profit margin over companies that have a low profit margin. As a result, companies with a high profit margin are considered capable of producing maximum profits by investors (Aulia et al., 2020).

\section{THEORITICAL REVIEW}

The relationship between the principal and the agent is discussed in agency theory. Different interests exist between company owners and investors as principals and management as agents. Management hopes that the company's profitability will impact the high compensation for its performance in this study. Simultaneously, the owner prefers a company that can continue to operate and generate profits and investment from investors. Agency conflicts can lead to profit and profit statements being managed opportunistically to maximize their own self-interest. If this occurs, the earnings quality will deteriorate.

The relationship between company management and stakeholders is explained by stakeholder theory. The management of the company is expected to work responsibly and contribute by stakeholder expectations. Profits from the company's operations, on the other hand, can be maximized, while losses to stakeholders can be minimized. Stakeholders' trust in the company will grow as the company's performance improves over time, and vice versa. Shareholders, employees, customers, suppliers, creditors, the government, and society are all stakeholders (Herlina and Permanasari, 2017). Profitability has a significant impact on stakeholders' desires in this study; thus, management must manage the company for the benefit of all stakeholders.

Profitability has a positive and significant effect on earnings quality, according to research findings (Salma and Riska, 2019) and (Zatira et al., 2020). The higher the company's profitability, the higher the company's profit quality; this will be a positive signal for investors to invest in the company in the hopes of making large profits (Zatira et al., 2020). However, according to the findings of the study (Setiawan, 2017), profitability has a significant negative impact on earnings quality. The following is the hypothesis:

\section{H1: Profitability has a positive and significant effect on earnings quality.}

The size of a company has an impact on the quality of its earnings. The size of a company directly relates to the quality of its earnings because the larger the company, the greater its business continuity in improving its financial condition, reducing the need for revenue manipulation (Setiawan, 2017). A growing business can easily attract capital, which is a source of expansion. Investors will well receive the company's earnings information. Investors will react strongly to a company with a high-profit growth rate because it can provide income in the future (Andryani, 2015).

According to (Sari and Badjra, 2016), the greater a company's assets are, the more mature the company is, and the better its prospects are for the future. Because of the size of the company, management is unable to manipulate profits. The company's financial 
performance is good because as the company grows in size, its chances of survival improve, as does its financial performance.

Company size is a group of companies divided into small, medium, and large companies (Anggarainy and Priyadi, 2019). Large corporations have several advantages over small and medium businesses. Large companies can more easily access capital from the capital market and negotiate better terms in various contracts related to their operations. Large companies also have an increasing number of external funding sources, making it easier to obtain loans. This is because large corporations are thought to have a better chance of winning in a competitive environment.

Agency theory discusses the relationship between principal and agent. company owners and investors as principals and management as agents have different interests. The research explains that the greater the company's size, the more complex the transaction will be, so that management hopes that the company will be able to get profits that attract investors. This desire will create a conflict between the principal and the agent. Agency conflicts can lead to opportunistically managing profit and profit statements to maximize their self-interest. If this happens, it will cause the earnings quality to decline.

Signaling Theory is a signal of a management action that informs investors how management sees its prospects. The manager is required to send the owner a signal about the company. Accounting information, such as financial reports, can be used to provide the signal. By reducing information asymmetry, businesses can improve the quality of their earnings. Information asymmetry occurs when the company's manager knows more about the company and its prospects. Providing signals to outsiders in the form of financial and non-financial data is one way to reduce information asymmetry. Uncertainty about the company's prospects will be reduced by providing positive and reliable financial information, thereby increasing its credibility and success (Sukmawati et al., 2014).

Company size has a positive and significant effect on earnings quality, according to research (Warianto and Rusiti, 2014), (Herlina and Permanasari, 2017) and (Jaya and Wirama, 2017). When it comes to investing their money, investors will look for companies that can deliver a high level of performance, ensuring that their money is put to good use. The larger a company is, the more focused it will be on improving financial performance, which will lead to it not practicing earnings management (Ananda and Ningsih, 2016). However, according to the findings of the study (Hakim and Abbas, 2019), company size has a negative and significant impact on earnings quality. The following is the hypothesis:

\section{H2: Firm size has a positive and significant effect on earnings quality.}

The Investment Opportunity Set has an impact on the quality of earnings as well (IOS). The Investment Opportunity Set (IOS) is a company opportunity to grow, according to (Sari and Budiartha, 2016). Investors with a high IOS are thought to be optimistic because they have a better chance of making money in the future. As a result, when a company's IOS is high, its value rises because more investors want to invest to earn a higher return in the future and generate quality profits.

Because IOS is an investment option, its value is dependent on future discretionary expenditures. The expected return is higher than the cost of equity (cost of equity), implying that profits can be made. As a result of the manager's behavior becoming unobservable (not observable), the client cannot determine whether the manager has acted by the client's 
wishes. The IOS of a company impacts how managers, owners, investors, and creditors perceive it (Sari, 2020).

The relationship between the principal and the agent is discussed in agency theory. Different interests exist between company owners and investors as principals and management as agents. According to this study, the conflict between the principal and the agent will be influenced by investment decisions in the form of a combination of assets owned and investment options in the future. Agency conflicts can lead to profit and profit statements being managed opportunistically to maximize their own self-interest. If this occurs, the earnings quality will deteriorate.

Signaling Theory is a signal for a management action that informs investors how management views its prospects. The manager is required to send the owner a signal about the company. Accounting information, such as financial reports, can be used to provide the signal. By reducing information asymmetry, businesses can improve the quality of their earnings. Information asymmetry occurs when the company's manager knows more about the company and its prospects. Providing signals to outsiders in the form of financial and non-financial data is one way to reduce information asymmetry. Uncertainty about the company's prospects will be reduced by providing positive and reliable financial information, thereby increasing its credibility and success (Sukmawati et al., 2014).

The results (Arisonda, 2018) and (Hakim and Abbas, 2019) found that IOS has a positive and significant effect on earnings quality. However, the study results (Jaya and Wirama, 2017) found that IOS has a negative and significant effect on earnings quality. The investment opportunity set illustrates the company's potential growth in the future that will have an impact on the quality of reported earnings. Investors who prioritize high-quality earnings can consider investing (Jaya and Wirama, 2017). Then the hypothesis is proposed:

\section{H3: Investment Opportunity Set has a positive and significant effect on earnings quality.}

This study refers to (Ginting, 2017), which looked at the impact of profitability, liquidity, and company size on financial statements' quality. Profitability variables, company size, and the Investment Opportunity Set (IOS) related to earnings quality are used in this study. Because earnings information is so important to investors when making investment decisions, the quality of earnings information in a company's financial statements is a major concern. IOS as a novelty variable, with IOS considerations as the foundation for determining future company growth classification. Because more investors are interested in investing in a high IOS company, its value will rise. Because several financial report scandals have occurred in service sector companies listed on the Indonesia Stock Exchange, this study will focus on them. On the other hand, service sector businesses are a muchneeded necessity for everyone, and their prospects are bright. Another reason for this study's existence was the inconsistency of previous studies' findings, which drew researchers to conduct it.

\section{METHODS}

This type of research is causal research using quantitative methods. This research aims to publish audited financial reports and publish them on the Indonesia Stock Exchange (IDX) for the period 2018 and 2019. The study population is the financial statements of 
manufacturing companies in the consumer goods industry sector that are listed on the IDX as many as 50 companies with purposive sampling technique with criteria: a) Trading sector service companies listed on the Indonesia Stock Exchange that have published financial reports in 2018 and 2019, b) Trading sector service companies listed on the Indonesia Stock Exchange that present financial reports on service companies in 2018 and 2019, and 3) Service companies trading sector listed on the Indonesia Stock Exchange which has positive commercial profits in 2018 and 2019 so that it becomes 38 company financial reports with two years of data so that the total sample to 76 financial statement data. Secondary data is collected through the Indonesian Stock Exchange website and analyzed with a multiple regression model with the Ordinary Least Square model using software Eviews 11 with the following equation:

$$
\mathrm{EQ}=\alpha+\beta 1 \mathrm{Prob}+\beta 2 \mathrm{SF}+\beta 3 \mathrm{IOS}+\mathrm{e}
$$

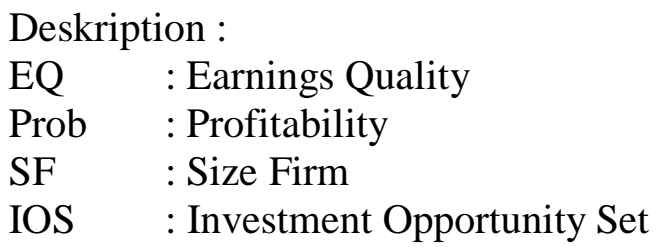

In this study, estimating linear equations using OLS, the BLUE assumption (Best Linear Unavailable Estimator) must be fulfilled, namely: 1) the expected value of the average error is zero. 2) fixed variables (homoscedasticity), 3) There is no relationship between the independent variables and the error term, 4) There is no serial correlation between errors, 5) There is no multicollinearity.

Table 1. Operational Definition

\begin{tabular}{|c|c|c|c|}
\hline No & Variable & $\begin{array}{c}\text { Variable } \\
\text { Definition }\end{array}$ & Formula \\
\hline 1 & $\begin{array}{l}\text { Earnings } \\
\text { Quality (Y) }\end{array}$ & $\begin{array}{l}\text { Is the quality } \\
\text { of } \\
\text { information } \\
\text { that is able to } \\
\text { show the } \\
\text { extent to } \\
\text { which profits } \\
\text { can influence } \\
\text { decision } \\
\text { making and } \\
\text { can be used } \\
\text { by investors } \\
\text { to assess the } \\
\text { company. }\end{array}$ & $Q E R=\frac{\text { Operating Cash Flow }}{\text { Company Net Profit }}$ \\
\hline 2 & $\begin{array}{l}\text { Profitability } \\
\text { (X1) }\end{array}$ & $\begin{array}{l}\text { the } \\
\text { company's } \\
\text { ability to } \\
\text { earn a profit }\end{array}$ & $R O A=\frac{\text { Net profit }}{\text { Total Asset }}$ \\
\hline
\end{tabular}


in relation to

sales

3 Size Firm The size of

(X3) the company

in improving

financial

performance.

4 Investment Investment opportunity decisions in set (X4) the form of a combination of assets and other investment options in the future.
FS $=$ Ln Total Assets

MBVA $=\frac{\text { Total assets }- \text { Total equity }+(\text { outstanding shares } \times \text { closing price })}{\text { Total Assets }}$

\section{RESULTS}

The data normality test results using the normal probability plot graph test show that the data in the study is suitable for use and is said to be expected. Figure 1 shows the JarqueBera value of 2.729 and a significance of 0.2555 or $25.50 \%>$ a significance level of $5 \%$, which means that the research variables are normally distributed.


Figure 1. Normality Test Results

Source : Output Eviews V.11 (2021)

To ensure that the estimated data are free from autocorrelation, this study uses the Brusch-Godfrey method as follows: 
Table 2. Autokorelasi Test Results

\begin{tabular}{llc}
\hline No & Info & Breusch-Godfrey test \\
\hline 1 & F. Statistik & 1,2982 \\
& Prob. F & 0,2795 \\
2 & Obs* R-Square & 2,7181 \\
& Prob. Chi-Square & 0,2569 \\
\hline
\end{tabular}

Source : Output Eviews V.11 (2021)

Prob Value. F of 0.2795 is greater than the 5\% significance level so that autocorrelation does not occur.Then the heteroscedasticity test is carried out to see whether there is a disturbance that appears in the regression function, it can be done with the $\mathrm{ARCH}$ test.

Table 3. Heteroskedasticity Test ARCH Results

\begin{tabular}{llc}
\hline No & Info & ARCH test \\
\hline 1 & F. Statistik & 0,235 \\
& Prob. F & 0,871 \\
2 & Obs* R-Square & 0,739 \\
& Prob. Chi-Square & 0,863 \\
\hline
\end{tabular}

Source : Output Eviews V.11 (2021)

Prob Value. From F count and Chi-Square count of all tests greater than the 5\% significance value, there is no heterocedasitisity in the equation model. Furthermore, the multicollinearity test uses Pearson Correlation as follows:

Table 4. Multikolinearitas Result

\begin{tabular}{llc}
\hline No & Auxiliary & Partial Regression \\
\hline 1 & $\mathrm{X} 1, \mathrm{X} 2, \mathrm{X} 3$ & 0,8123 \\
2 & $\mathrm{X} 2, \mathrm{X} 1, \mathrm{X} 3$ & 0,3773 \\
3 & $\mathrm{X} 3, \mathrm{X} 1, \mathrm{X} 2$ & 0,2390 \\
\hline
\end{tabular}

Source: Output Eviews V.11 (2021)

The test results show that the coefficient value between variables is smaller than 0.9 , so this research data does not have a multicollinearity problem.

Table 5. Coefficient of Determination

\begin{tabular}{cccl}
\hline R Squared & $\begin{array}{c}\text { Adjusted R- } \\
\text { Squared }\end{array}$ & $\begin{array}{c}\text { Coefficient of } \\
\text { Determination }\end{array}$ & \multicolumn{1}{c}{ Result } \\
\hline & & $\begin{array}{l}\text { Effect Probability, Size } \\
\text { Company and Investment } \\
\text { Opportunity Set to }\end{array}$ \\
0.366 & 0.335 & Earnings Quality 33,50\% \\
\hline
\end{tabular}

Source : Output Eviews V.11 (2021)

The value of Adjusted $\mathrm{R}$ square (Adj. $\mathrm{R}^{2}$ ) obtained is 0.335 or $33.50 \%$, which explains that earnings quality is influenced by Effect Probability, Size Company and Investment Opportunity Set to Earnings Quality. 
Table 6. Partial Test Results

\begin{tabular}{lcccc}
\hline \multicolumn{1}{c}{ Variable } & B & t & Sig. & Result \\
\hline Contant & 0,411 & 2,686 & 0.000 & \\
Probability & 0,014 & 2,251 & 0.002 & Accepted \\
Size Company & 1,157 & 4,048 & 0.000 & Accepted \\
Investment Opportunity Set & 0,122 & 2,686 & 0.000 & Accepted \\
\hline
\end{tabular}

Source : Output SPSS, 2021

The results of the multiple linear regression test shown in Table 3 show that the regression coefficient values formed in this test are:

$\mathrm{Y}=0,411+0,014 \mathrm{X} 1+1,157 \mathrm{X} 2+0,122 \mathrm{X} 3+\mathrm{e}$

These results equation can be explained as follows: the coefficient of the probability variable is 0.014 with a positive direction, which means that if there is an increase in probability, the earnings quality will increase by 0.014 . The size company variable coefficient is 1,157 with a positive direction, which means that if there is an increase in size company, the earnings quality will increase by 1,157 . The Investment Opportunity Set variable coefficient is 0,122 with a positive direction, which means that if there is an increase in Investment Opportunity Set, the earnings quality will increase by 0,122.

\section{DISCUSSION}

Based on the first hypothesis test, it was found that probability has a positive and significant effect on earnings quality. This means that the hypothesis tested is accepted. Companies that have good profitability are able to improve the quality of earnings owned by the company because profitability is a measure of the company's ability to earn profits. A company that manages to maintain profitability can certainly be sure to run its business well because when the company is able to run its business well, it means that the company is able to work optimally to obtain maximum profit. Companies that have good profitability are able to improve the quality of earnings owned by the company because profitability measures the company's ability to earn profits. However, if the profitability is low, the company will have a bad image in the eyes of investors, therefore the company will try to make the profitability level high. This motivates the company to tend to increase profits, so that the existence of profit manipulation can cause profits that are not visible and the quality of the company's earnings decreases.

The results of this study support the statement (Syawaluddin et al., 2019) that the higher the company's profitability, the better the profit quality the company gets. Profitability is a factor that should receive important attention because in order to carry out its life, a company must be in a profitable state. Without profit, it will be difficult for the company to withdraw capital from the company's ability to generate profits in its operations (profitability) is the main focus in assessing company performance because company profit is not only an indicator of the company's ability to fulfill its obligations to its funders. in the creation of company value that shows the company's future prospects. 
The results of this study support Agency Theory which discusses the relationship between principal and agent. company owners and investors as principals and management as agents have different interests. In this study, management hopes that the profitability obtained by the company will affect the high compensation for its performance, while the owner tends to want a company that can continue to operate and generate profits and investment from investors. This difference in interests will create an agency conflict which can lead to the management of profit and profit statements in an opportunistic way to maximize their personal interests. If this happens it will cause the quality of earnings to decline.

Stakeholder theory is also supported in this study which explains the relationship between company management and stakeholders. The management of the company is expected to work responsibly and contribute according to the expectations of stakeholders, although the profits from the company's activities can be maximized and the losses that can affect stakeholders can be minimized. If the company's performance gradually improves over time, stakeholders' trust in the company will increase, and vice versa. These stakeholders include shareholders, employees, customers, suppliers, creditors, government and society (Herlina and Permanasari, 2017). In this study, profitability greatly influences the desires of stakeholders, therefore management must manage the company for the benefit of all stakeholders.

The results of this study support the results of research (Salma \& Riska, 2019) and (Zatira et al., 2020) which found that profitability has a positive and significant effect on earnings quality. The higher the profitability generated by the company, the higher the profit quality generated by the company, this will be a positive signal for investors to invest in the company in the hope of getting big profits (Zatira et al., 2020).

Based on the hypothesis second test, it was found that size firm has a positive and significant effect on earnings quality. This means that the hypothesis tested is accepted. If the higher the size firm in a company, the greater the quality of earnings in that company. Most manufacturing companies are large companies, but investors prefer to see the company's market conditions in general rather than seeing its total assets. Company size can only be used to classify companies into large, medium, or small companies.

Even though a company that has a large amount of total assets and is classified as a large company that can easily have access to funding sources and has a good level of performance, it does not guarantee that the quality of profits generated by the company will be high. This is because companies that are relatively large in size have great profit potential as well, because the company's infrastructure is large, the company's operating costs are also large.

The results of this study support the statement (Pardosi et al., 2019) that company size affects the quality of company earnings, because it is easier for large companies to find investors who want to invest and obtain credit than small companies. Companies with high assets are considered to be less likely to transport assets, so that large companies tend to have more debt than small companies.

The results of the study support Agency Theory which discusses the relationship between principal and agent. company owners and investors as principals and management as agents have different interests. The research explains that the greater the size of the company, the more complex the transaction will be, so that management hopes that the company will be able to get profits that attract investors. This desire will create a conflict 
between the principal and agent. This agency conflict can lead to managing the income statement in an opportunistic way to maximize their personal interests. If this happens it will cause the quality of income to decline.

The results of this study also support the theory of signaling theory as a signal of an action taken by company management, which provides clues to investors about how management views the company's prospects. The manager is obliged to provide a signal about the company to the owner. The signal given can be done through disclosing accounting information such as financial reports. Companies can improve the quality of company earnings by reducing information asymmetry. Information asymmetry occurs when the manager, as the manager of the company, knows more company information and future prospects. One way to reduce information asymmetry is to provide signals to outsiders. in the form of financial information, but also non-financial. By providing positive and reliable financial information, uncertainty about the company's future prospects will be reduced, thereby increasing the company's credibility and success (Sukmawati et al., 2014).

The results of this study support the results (Warianto and Rusiti, 2014), (Herlina and Permanasari, 2017) and (Jaya and Wirama, 2017) found that company size has a positive and significant effect on earnings quality. Investors in investing their capital will choose companies that are able to involve good performance so that the invested capital will later get profitable results. The greater the size of a company, the higher the company's going concern will be in improving financial performance which will cause the company not to practice earnings management (Ananda and Ningsih, 2016).

Based on the third hypothesis test, it was found that Investment Oppurtunity Set has a positive and significant effect on earnings quality. This means that the hypothesis tested is accepted. This is because companies that have a high set of investment opportunities are constantly expanding their business strategies, and will increasingly need external funds. If the condition of the company is very good, the management will tend to prefer new investment rather than paying high dividends. Firm that have a high investment opportunity set value are not because the market values the assets owned by these companies higher than their book value. But this value is obtained due to the low value of the company's assets and the high negative equity value. This reason is why investors do not only see the high investment opportunity set value in making their investment decisions.

The results of this study support Agency Theory which discusses the relationship between principal and agent. company owners and investors as principals and management as agents have different interests. This research explains that investment decisions in the form of a combination of assets owned and investment options in the future will affect the conflict between the principal and the agent. This agency conflict can lead to managing the income statement in an opportunistic way to maximize their personal interests. If this happens it will cause the earnings quality to decline.

The results of this study support the signaling theory as a signal of an action taken by company management, which provides guidance for investors on how management views the company's prospects. The manager is obliged to provide a signal about the company to the owner. The signal given can be done through disclosing accounting information such as financial reports. Companies can improve the quality of company earnings by reducing information asymmetry. Information asymmetry occurs when the manager, as the manager of the company, knows more company information and future prospects. One way to reduce information asymmetry is to provide signals to outsiders. in the form of financial 
information, but also non-financial. By providing positive and reliable financial information, uncertainty about the company's future prospects will be reduced, thereby increasing the company's credibility and success (Sukmawati et al., 2014).

The results of this study support the results (Arisonda, 2018) and (Hakim and Abbas, 2019) found that the investment opportunity set has a positive and significant effect on earnings quality. This is because the high investment opportunity set tends to be considered positive by investors because it has more prospects for profits in the future. Thus, when a company has a high investment opportunity set, the value of the company will increase because more investors are attracted to invest in the hope of obtaining a greater return in the future. This causes the possibility of company management to carry out earnings management because it is to maintain company growth (Tanjung, 2019).

\section{CONCLUSION}

This research is conducted on companies in the service industry listed in the Indonesian stock exchange to test their profitability, corporate size, and investment opportunities. The analysis results show that profitability, company size, and investment opportunity simultaneously have a positive and significant effect on income quality. However, partial profitability has a positive and significant impact on income quality, which means that the higher its profitability, the higher its income quality. Company size has a positive and significant impact on income quality, which will enhance income quality for companies of a large size. The investment opportunity has a positive and significant impact on earnings quality, which means that a high investment chance will increase income quality, as more investors are interested in investing.

Investors should pay more attention to the disclosure of information in the company's financial statements to consider investment decisions to be made because it is possible for some companies to carry out earnings management so that the company generates significant profits presented in the financial statements. It is also suggested that investors assess the quality of the company's earnings by comparing its operating net income with operating net cash flow. The closer the profit to the operating cash flow, the more qualified the profit is. Because this study only uses the trade services sector as an observation sample, further research is expected to use a more comprehensive research sample: mining, pharmaceutical, food, and beverage finance, services, and property sectors.

\section{REFERENCES}

Agustin, T., dan Hermanto, S. B. (2015). Pengaruh Nilai Perusahaan, Profitabilitas dan Risiko Keuangan Terhadap Earnings Management. Jurnal Ilmu \& Riset Akuntansi, 4 (1).

Amin, A. (2015). Pengaruh Perputaran Kas, Perputaran Persediaan, Pertumbuhan Penjualan Terhadap Profitabilitas Pada Perusahaan Food And Beverageyang Terdaftar Di Bursa Efek Indonesia. Akmen. Jurnal Ilmiah. https://doi.org/10.37476/akmen.v12i4, 12 (4), 525-533.

Ananda, R., dan Ningsih, E. S. (2016). Pengaruh Likuiditas, Kepemilikan Institusional, Dan Ukuran Perusahaan Terhadap Kualitas Laba (Pada Perusahaan Manufakturyang 
Terdaftar di Bursa Efek Indonesia Tahun 2010-2014). Jurnal Ilmiah Mahasiswa Ekonomi Akuntansi (JIMEKA), 1 (2), 277-294.

Andryani, I. (2015). Pengaruh Rasio Keuangan Terhadap Pertumbuhan Laba Pada Perusahaan Pertambangan Yang Terdaftar Di Bursa Efek Indonesia. Jurnal Manajemen dan Bisnis Sriwijaya, 13 (3).

Anggarainy, L., dan Priyadi, M. P. (2019). Pengaruh Struktur Modal, Pertumbuhan Laba, Kualitas Audit, Dan Ukuran Perusahaan Terhadap Kualitas Laba. Jurnal Ilmu dan Riset Akuntansi, 8 (6), 1-20.

Arisonda, R. (2018). Pengaruh Struktur Modal, Likuiditas, Pertumbuhan Laba, Ukuran Perusahaan Dan Invesment Opportunity Set (Ios)Terhadap Kualitas Laba Pada Perusahaan Manufaktur Yang Terdaftar Di Bei. Jurnal ADDVANCE, 5 (2).

Asniwati. (2020). Pengaruh Rasio Likuiditas, Solvabilitas, Dan Profitabilitas Terhadap Kinerjakeuangan Pada Pt. Midi Utama Indonesia Tbk Yang Terdaftar Di Bursa Efek Indonesia. Jurnal Economix, 8 (1), 246-257.

Aulia, I., Diah PA, E., danTiswiyanti, W. (2020). Faktor-faktor yang Mempengaruhi Kualitas Laba (Studi Pada Perusahaan Perusahaan di Bursa Efek Indonesia Tahun 2015-2018). JAR. (Jambi Accounting Review), 1 (1).

Dewi, N. S., dan Yadnyana, I. (2019). Pengaruh Profitabilitas dan Leverage Pada Earning Response Coefficient Dengan Ukuran Perusahaan Sebagai Variabel Pemoderasi. EJurnal Akuntansi, 26 (3), 2041-2069.

Ginting, S. (2017). Pengaruh Profitabilitas, Likuiditas Dan Ukuran Perusahaan Terhadap Kualitas Laba Pada Perusahaan Manufaktur Yang Terdaftar Di Bursa Efek Indonesia. Jurnal Wira Ekonomi Mikroskil, 7( 2), 227-236.

Hakim, M. Z., dan Abbas, D. S. (2019). Pengaruh Ukuran Perusahaan, Struktur Modal, Likuiditas, Investment Opportunity Set (Ios), Dan Profitabilitas Terhadap Kualitas Laba (Perusahaan Makanan dan Minuman yang Terdaftar di Bursa Efek Indonesia Tahun 2013-2017). Competitive Jurnal Akuntansi dan Keuangan, 3 (2).

Herlina, H., dan Permanasari, M. (2017). Faktor-Faktor Yang Mempengaruhi Kualitas Laba Pada Perusahaan Publik Manufaktur. Jurnal Bisnis dan Akuntansi, 19 (1a), 325-334.

Jaya, K. A., dan Wirama, D. G. (2017). Pengaruh Investment Opportunity Set, Likuiditas, dan Ukuran Perusahaan Pada Kualitas Laba. E-Jurnal Akuntansi, 21 (3), 2195-2221.

Kurniawan, E., dan Aisyah, S. N. (2020). Pengaruh Set Kesempatan Investasi, Konservatisme dan Pertumbuhan Laba Terhadap Kualitas Laba Pada Perusahaan Manufaktur Di Indonesia. AKRUALJurnal Akuntansi dan Keuangan, 2 (1).

Kurniawati, W. (2016). Prediksi Laba Di Masa Yang Akan Datang Dengan Rasio Keuanganpada Perusahaan Manufaktur Yang Terdaftar Di Bursa Efek Indonesia Periode 2010-2014. Jurnal Perilaku Dan Strategi bisnis, 4 (1).

Mahkamah, M., Susanto, E., dan Sari, V. N. (2020). Analisis Determinan Persistensi Laba. Jurnal STIE Semarang, 12 (3).

Marpaung, E. I. (2019). Pengaruh Leverage, Likuiditas, dan Ukuran PerusahaanSebagaiVariabel Moderasi Terhadap Kualitas Laba. JAFTA, Program Studi Magister Akuntansi., 1 (1).

Marsela, S. Y., dan Maryono, M. (2017). Pengaruh Good Corporate Governance, Leverage, Profitabilitas dan Ukuran Perusahaan Terhadap Kualitas Laba. Dinamika Akuntansi, Keuangan dan Perbankan, 6 (1). 
Maulidasari, D. N. (2020). Pengaruh Informasi Arus Kas Dan Laba Bersih Terhadap Volume Perdagangan Saham Pada Perusahaan Manufaktur Sektor Otomotifyang Terdaftar Di Bei Periode 2009-2012. Jurnal Ilmu Manajemen Retail (JIMAT), 1 (1).

Muhammad, T. T., dan Rahim, S. (2015, Juni). Pengaruh Tingkat Likuiditas Dan Profitabilitasterhadap Harga Saham Pada Perusahaan Manufakturyangterdaftar Di Bursa Efek Indonesia (BEI). Jurnal Akuntansi Aktual, 3 (2), 117-126.

Pardosi, S. D., Sihombing, Y. R., Samosir, D. M., Purba, F. A., dan Simangunsong, N. A. (2019). Pengaruh Firm Size, Capital Structure, Dan Investmet Opportunity Set (Ios)Terhadap Kualitas Laba Padaperusahaan Perdagangan, Jasa, Dan Investasi Yang Terdaftar Di Bursa Efek Indonesia Periode 2014-2017. MAPAN: Jurnal Manajemen Akuntansi Palapa Nusantara, 4 (1).

Polii, J. C., Sabijono, H., dan Elim, I. (2019). Analisis Laporan Arus Kas Untuk Menilai Kinerja Keuangan Pada Perusahaan Telekomunikasi Di Bursa Efek Indonesia. Jurnal EMBA, 7 (3), 4096-4105.

Salma, N., dan Riska, T. J. (2019). Pengaruh Rasio Leverage, Likuiditas, Profitabilitas Terhadap Kualitas Laba Perusahaan Makanan Minuman BEI. Jurnal Competitive, 14 (2).

Sanjaya, S., dan Rizky, M. F. (2018). Analisis Profitabilitas Dalam Menilai Kinerja Keuangan Pada PT. Taspen (Persero) Medan. Jurnal KITABAH, 2 (2).

Sari, F. D. (2020). Pengaruh Persistensi Laba, Investment Opportunity Set, Asimetri Informasi Terhadap Kualitas Labapadaperusahaan Manufaktur Yang Terdaftar Di Beipadatahun 2015-2019. Jurnal Mitra Manajemen(JMM Online), 4 (11), 1573-158.

Sari, N. P., dan Budiartha, I. (2016). Pengaruh Investment Opportunity Set (IOS) Pada Kebijakan Dividen Tunai Dengan Umur Perusahaan Sebagai Variabel Pemoderasi. EJurnal Ekonomi dan Bisnis, 5(5), 1335-1358.

Sari, N. S., dan Badjra, I. B. (2016). Pengaruh Likuiditas, Ukuran Perusahaan, Leverage Dan Jaminan Terhadap Peringkat Obligasi Pada Sektor Keuangan. E-Jurnal Manajemen Unud, 5 (8).

Setiawan, B. S. (2017). Pengaruh Ukuran Perusahaan, Profitabilitas, Likuiditas Dan Leverage Terhadap Kualitas Laba Pada Perusahaan Manufaktur Industri Barang Konsumsi yang Terdaftar Di BEI. Jurnal Menara Ilmu, XI (77), 36-46.

Sukmawati, S., Kusmuriyanto, K., dan Agustina, L. (2014). Pengaruh Struktur Modal, Ukuran Perusahaan, Likuiditas Dan Return On Asset Terhadap Kualitas Laba. Accounting Analysis Journal, 3 (1).

Syawaluddin, S., Sujana, I., dan Supriyanto, H. (2019). Pengaruh Struktur Modal, Likuiditas, Ukuran Perusahaan, Pertumbuhan Laba Dan Profitabilitas Terhadap Kualitas Laba. Jurnal Entries, 1 (1).

Tanjung, P. R. (2019). Pengaruh, Debt To Equity Ratio, Likuiditas Dan Investment Opportunity Set (Ios) Terhadap Kualitas Laba. Publik : Jurnal Ekonomi Publik, 15 (2).

Warianto, P., dan Rusiti, C. (2014). Pengaruh Ukuran Perusahaan, Struktur Modal, Likuiditas Dan Investment Opportunity Set (Ios) Terhadap Kualitas Laba Pada Perusahaan Manufaktur Yang Terdaftar Di Bei. Modus Journals., 26 (1).

Zatira, D., Sifah, H. N., dan Erdawati, L. (2020). Pengaruh Ukuran Perusahaan, Struktur Modal, Likuiditas, dan Profitabilitas Terhadap Kualitas Laba Pada Perusahaan Food and Beverage yang Terdaftar di BEI Periode 2013-2019. Prosiding Konferensi 
Andriani, Nurnajamuddin, Rosyadah: Does Profitability, Firm Size, and Investment ..

Nasional Ekonomi Manajemen dan Akuntansi (KNEMA) (pp. 1-13). Jakarta: Universitas Muhammadiyah Jakarta. 